\title{
Talking cure and curing talk
}

Miles Little

J R Soc Med 2005;98:210-212

I don't feel that I know you, but I have a strong feeling that you regard 2005 as being a long time ago and as having been medically naïve. Our views about genetics, cloning and cures for cancer probably look old-fashioned. Dear reader in 2055 you undoubtedly know a great deal more, and have quite different ideas, about the realities of resource allocation, bioethics, and poverty. AIDS and SARS control will be accepted parts of your life, and somewhat passé as items of interest.

One thing I do feel fairly confident about. I'll bet that people in your community still tell stories - funny stories, sad ones, stories about heroism and cowardice, fear and courage, love and hate, pain and pleasure. Fifty years isn't so very long, and people will still need stories to make sense of experiences, to give logic and meaning to their lives, and to establish and affirm their identities. ${ }^{1-3}$

They probably won't tell their stories in doctor's offices - if they still exist and everything isn't being transacted on the Web. Doctors have always been a bit funny about narratives. Patients offer stories. Doctors take histories. They interrupt, direct, edit, reinterpret and truncate. ${ }^{4} \mathrm{~A}$ man recovering from bone-marrow transplantation wants to tell the story of illness, treatment and its aftermath:

'Old friends don't recognize me any more. I've changed. I've lost my old functions in life. I was a general practitioner. The pharmacist near my old rooms filled a prescription for me the other day, and didn't realize who I was. He said "My God I thought you were dead". I might as well be dead. I'm doing nothing. My wife earns the money. I've got no status, no purpose. I really am in God's waiting room.'

His oncologist writes a one word summary: Depressed.

The patient wants to tell his story. The doctor wants an ICD-10 category into which the narrative can be packaged. That's how doctors practise now, and I'm sure that's how they'll practise in 2055. There's a lot to be said for

Emeritus Professor Miles Little, FRCS, formerly Professor of Surgery at the University of Sydney, was founder and Director of the Centre for Values, Ethics and the Law in Medicine.

Centre for Values, Ethics and the Law in Medicine, University of Sydney, Sydney, NSW 2006, Australia objectivity, categorization and standardization. Doctors have to be careful with their time and patients suffer when they aren't. But there's also unfortunately a lot to be lost by not listening to narratives. The medical history sacrifices almost all of their richness. The medical transaction can be an awful example of sense and meaning passing one another by. On one side, a person suffering has a story waiting to be heard. On the other, the healer has time only to select what is relevant to the diagnosis and management of illness and disease - within the medical model.

The past couple of decades have seen medical and sociological researchers paying close attention to narrative. ${ }^{5-11}$ Ethicists have developed a discipline of 'narrative ethics' ${ }^{12,13}$ Medical advocates have pointed to the value of narrative therapy for chronic and obscure illnesses. ${ }^{14}$ Psychologists and theorists of mind have written extensively about the role of narrative in the development of identity and the creation of meaning in a person's life. ${ }^{1,3}$ Yet there remains a block to the acceptance of narrative as something real, as a genuine contributor to evidence-based medicine. In part, it seems to be that story-telling is so familiar as to be unacceptable either as a subject for or as a means of doing research. Perhaps the very enthusiasm of its advocates and their claims for its privileged status antagonize those who are not converted and whose training is in quantitative rather than qualitative research.

Yet narrative research has a long and distinguished history: Propp's analysis of the structure of fairy tales, ${ }^{15}$ Bakhtin's work on discourse, ${ }^{16}$ Malinowski's ethnography ${ }^{17}$ all relied on the analysis of narrative. More recently, illness narrative has stimulated sophisticated examinations and practical insights by Kleinman, ${ }^{10}$ Frank, ${ }^{9}$ Mattingly, ${ }^{6,7}$ Charon, ${ }^{13}$ Brody ${ }^{18}$ and many others. Medical clinicians, psychiatrists and psychologists, anthropologists and sociologists have all used narrative to develop new understandings and new categories that can be used for quantitative analysis.

Narrative, of course, has its limits, and it doesn't solve all problems. ${ }^{19}$ But let me tell you a story. In 1995, I was part of a committee charged with developing outcome measures for three index cancers that a department of health could use in cost-benefit equations for policy development. The people on the committee were experienced, educated and informed, and included 
physicians and surgeons, nurses, oncologists, radiotherapists, consumers, economists and health administrators. We met each month for a year. At the final meeting, the chair summed up sadly by agreeing that we had 'learned a lot' but had failed to reach agreement on the meaning of the word outcomes. To the clinicians, it meant complications and survivals; to economists and administrators, it included cost and benefits; and to consumers, important components were the processes of diagnosis, treatment and follow-up. The whole conversation had bogged down because each of us began by thinking that everyone knew what 'outcomes' meant. When we realized that there was no common meaning, we spent the rest of the year arguing about whose meaning would prevail. We reached no agreement.

Puzzled by this debacle, I started a research group at the University of Sydney, partly so that I could think about the problem of incompatible discourses. Narrative research seemed to offer a useful approach, and we elicited biographical narratives from patients with cancer, from their clinical carers, and from other stakeholders in healthcare. We sought to map their values, and to learn how linguistic barriers develop. To shorten the story, the research rapidly proved that I would need another lifetime to do it justice. It was immensely productive $e^{20}$ and it attracted a multidisciplinary group of the best collaborators I have ever worked with in a long career in surgery and research. The University Centre that emerged from the work attracts all sorts of national and international interest.

The most telling advantage of qualitative research and work with narrative is the emergence of the unexpected. If you insist on quantitative methods, you enter your research programme with the things to be measured already defined. Your 'instruments' can only work within that range. Qualitative research encourages the investigator to identify new categories for analysis, which emerge from the source material. Within a year of starting our project, we had noted that the experience of surviving cancer has an unexpected dark side, and we went on to develop an approach to this problem that continues to evolve in our research programme. It gives insights to those with postcancer distress, has applications in therapy, and raises important questions about the nature of extreme experience and its effects. ${ }^{21}$

For those who remain sceptical about qualitative research, one of our group, Christopher Jordens, has developed ways of analysing narrative that depend on linguistic classification, coding, computing and counting. ${ }^{11,22}$ What he has done is illuminating and objective, and in some ways bridges the divide between qualitative and quantitative ways of working. It also lends strong support to purely qualitative methods. ${ }^{23}$
I am telling you this because, as I approach the end of my life, I want to feel that my narrative has some meaning, that someone may have listened to something that I've said and may use something that I've done. Like all the patients I saw during my years in practice, I want to be recognized as a human being with some validity, even in these declining years. By 2055 I will be long dead and forgotten, but people will still be telling stories. I do hope that medical people will by then have rediscovered the everyday art of listening to them, not just in the tearoom or over the kitchen table at home, but also in the setting of their practices. Telling and hearing stories is fundamental to being human. Their extreme familiarity should not blind us to their power, now or in 2055.

With sincere good wishes and paternal greetings.

\section{REFERENCES}

1 Hermans HJM, Kempen HJG. The Dialogical Self: Meaning as Movement. San Diego: Academic Press, 1993

2 Rose N. Inventing Our Selves-Psychology, Power and Personhood. New York: Cambridge University Press, 1996

3 Harré R, Gillett G. The Discursive Mind. Thousand Oaks: Sage, 1994

4 Little M. Humane Medicine. Cambridge: Cambridge University Press, 1995

5 Frank AW. The rhetoric of self-change: illness experience as narrative. Sociol Quart 1993;34:39-52

6 Mattingly C. Healing Dramas and Clinical Plots: The Narrative Structure of Experience. Cambridge: Cambridge University Press, 1998

7 Mattingly C, Garro LC, eds. Narrative and the Cultural Construction of Illness. Berkeley: University of California Press, 2000

8 Cassell EJ. Why should doctors read medical books? Ann Intern Med 1997; 127:576-8

9 Frank AW. The Wounded Storyteller: Body, Illness, and Ethics. Chicago: University of Chicago Press, 1995

10 Kleinman A. The Illness Narratives-Suffering, Healing and the Human Condition. New York: Basic Books, 1998

11 Jordens CFC, Little M, Paul K, Sayers E-J. Life disruption and generic complexity: a social linguistic analysis of narratives of cancer illness. Soc Sci Med 2001;53:1227-36

12 Charon R. Narrative contributions to medical ethics: recognition, formulation, interpretation, and validation in the practice of the ethicist. In: DuBose ER, Hamel R, O'Connell L-J, eds. A Matter of Principle: Ferment in US Bioethics. Valley Forge: Trinity International Press, 1994

13 Charon R, Montello M, eds. Stories Matter: The Role of Narrative in Medical Ethics. Routledge: New York, 2002

14 Greenhalgh T, Hurwitz B, eds. Narrative Based Medicine: Dialogue and Discourse in Clinical Practice. London: BMJ Books, 1998

15 Propp V. Morphology of the Folktale (1928) 2nd edn. Austin: University of Texas Press, 1968

16 Bakhtin MM. The Dialogic Imagination. Austin: University of Texas Press, 1981

17 Malinowski B. Supplement I. The problem of meaning in primitive languages. In: Ogden CK, Richards IA, eds. The Meaning of Meaning: A Study of the Influence of Language upon Thought and of the Science of Symbolism. London: Routledge \& Kegan Paul, 1947:296-336

18 Brody H. Stories of Sickness. Oxford: Oxford University Press, 2003 
19 Nelson JL, ed. Stories and Their Limits: Narrative Approaches to Bioethics. Routledge: New York, 1997

20 Kerridge I, Jordens C, Sayers E-J, eds. A Miles Little Reader: Restoring Humane Values to Medicine. Sydney: Desert Pea Press, 2003

21 Little M, Jordens CFC, Paul K, Sayers E-J. Surviving Survival: Life After Cancer. Marrickville: Choice Books, 2001
22 Jordens CFC, Little M. 'In this scenario, I do this, for these reasons': narrative, genre and ethical reasoning in the clinic. Soc Sci Med 2004;58:1635-45

23 Denzin NK, Lincoln YS, eds. Handbook of Qualitative Research. Thousand Oaks: Sage, 1994 